\title{
Evaluation of the Nutritional Status of Adult Patients at the Inpatient Department of Internal Medicine in Some Jeddah Hospitals
}

\author{
Asmaa Saleh Ahmed Zahrani ${ }^{1}$ and Mohamed Nabil Basma ${ }^{2}$
}

\begin{abstract}
This study aimed to evaluate the nutritional status of the adult patients at the inpatient department of internal medicine in some hospitals in Jeddah. The number of respondents was 166 patients, and the numbers of them with different chronic diseases and cancer were 88 patients and 31 patients, respectively; while the remaining(47) patients suffering from different diseases. Questionnaire was used as a tool of collecting data which included social and economic data. Three methods had been used in the study to assess the nutritional status: anthropometric measurements, Identify the adequacy of nutrient intake, and laboratory analysis. The results showed that the mean body mass index(BMI)of inpatients was $\left(26.12 \pm 7.23 \mathrm{~kg} / \mathrm{m}^{2}\right)$. The calorie intake of the majority of the studied sample was less than the adequate calories intake per day. Intakes of $(44 \%),(38.7 \%),(23.1 \%)$ of patients with chronic diseases, cancer and various diseases, respectively were less than the recommended intake. While it was found that the entire respondents' intake was less than adequate intake of fat per day. A statistically significant relationship was found between the level of albumin, creatinine, and hemoglobin and the types of disease. There was no statistical significant relationship between the level of white blood cells and the type of disease.
\end{abstract}

\section{INTRODUCTION}

Nutritional care is an important aspect of health welfare, one of the important pillars of treatment. The Department of Nutrition at any hospital plays an integral role with the other parties for health care (American Dietetic Association, 2000).

Arrow (1997) noted that malnutrition diseases were spreading among inpatients in hospitals according to the study conducted by the Heartland Hospital in Australia. It was also found that there was an evident relationship between malnutrition and the inpatient length of staying in hospitals, whereby the patient's stay in hospital for a long period leads to great danger in his health which was manifested in the form of lack of appetite and loss of body weight.

A study by Ulibarri, et al. (2002) in Madrid hospitals found that $25-50 \%$ of hospital inpatients were suffering from varying degrees of malnutrition during their period of stay in the hospital. The study recommended the need

\footnotetext{
${ }^{1}$ College of Education for Home Economics and Art Education.

King Abdel Aziz University

${ }^{2}$ Faculty of Agriculture, Home Economics Department,

Alexandria University

Received October 7, 2012, Accepted November 25, 2012.
}

of early intervention in cases of severe malnutrition to reduce mortality or other diseases and also to reduce material costs incurred by hospitals and by raising the level of nutritional care and food awareness.

Although much attention had been given by the representatives for nutrition Management of the Saudi Ministry of Health in providing good nutrition for hospital inpatients. It had been observed through recent studies a lot of reluctance of inpatients to eat the food served to them due to lack of food awareness which has had the greatest implication on the emergence of nutrition and health problems they had (Al Shoshan, 1992).

In a study conducted by Cereceda, et al. (2003) on the inpatient department of internal medicine and General Surgery, it was found that $(18.20 \%)$ of the malnourished sample in the private medical ward and that malnutrition was manifested through weight loss by more than $(5 \%)$ of body weight and low in fat and muscle body mass. It turned out that $(40.8 \%)$ of the respondents consumed less of their nutrients; and $(37.7 \%)$ of them suffered from loss of appetite. Other malnutrition related diseases and circulatory problems had also been identified. Therefore, the aim of this study was to evaluate the health and nutritional status of patients at the Inpatient Department of Internal Medicine in some hospital in Jeddah.

\section{MATERIALS AND METHODS}

The study was conducted in both King Fahd Hospital and King Abdul Aziz Hospital, which are the two largest government hospitals of the Ministry of Health in the city of Jeddah. There were 792 hospital beds in the Medical department of King Fahd Hospital, while the number of hospital beds in the Medical Department at King Abdul Aziz was 434 beds. The number of the studied sample was 166 patients, 117 patients from King Fahd Hospital and 49 from King Abdul Aziz Hospital. The patients were divided into three categories:

1- 88 patients with chronic diseases, such as hypertension, diabetes mellitus, chronic liver disease ... comprising $53 \%$ of the total sample. 
2- 31 patients with different types of cancer such as bladder, breast, colon cancer ... comprising of $18.7 \%$ of the sample.

3- The rest of the patients (47) with other diseases (Sickle cell anemia, Iron deficiency anemia, Rheumatic ...) comprising $28.3 \%$ of the sample.

An interview questionnaire was used as a tool for collecting the data. It included social and economical data. The study used three methods to assess the nutritional status: First: anthropometric measurements (physical) measurement of height and weight, body mass index, mid-arm circumference. Second: Food intake in the previous 24 hours was estimated using the Arab Program for food analysis. (Al-Hazza, 2009) Nutrient intake was estimated and compared with the standard Dietary Reference Intake (DRI) (Food and Nutrition Board, 1997-2004) Ravasco, et al. 2004) The adequacy of nutrient intake was also identified (less than adequate - adequate - more than adequate).Third: laboratory tests: plasma albumin (serum albumin), creatinine Index, numbers of white blood cells and red blood cells, hemoglobin - hematocrit. Results were analyzed using the computer program (SPSS V 15).

\section{RESULTS AND DISCUSSION}

Table (1) shows that $64.4 \%, 16.7 \%$ and $18.9 \%$ of studied patients with chronic diseases, cancer and other diseases, respectively, were males versus $39.5 \%, 21.0 \%$ and $39.5 \%$ were females. A statistically significant relationship ( $\mathrm{P}=0.003)$ was found between sex and type of disease. It turned out that the prevalence of chronic diseases among males was higher than in females, while the spread of various diseases was higher among females.

The age of the studied sample ranged between (1664 years) divided into three age groups (as shown from Table 1): $(16-19),(20-44)$, and $(54-64)$ years old. The percentage of these three age groups were $(9 \%)$, $(52.4 \%)$ and $(38.6 \%)$, respectively (Table 1$)$ where it was found that $(74.5 \%)$ of patients with various diseases and $(45.2 \%),(43.2 \%)$ of those with cancer and chronic diseases, respectively in the age group of (20-44 years old). As it turned out two third of the patients with chronic diseases $(51.1 \% \%)$ and $(29 \%),(21.3 \%)$ of those with cancer and various diseases respectively fell within the age group of (45 - 64 years). It was also found that (25.8\%) of cancer patients fell within the age group of (16- 19 years old) while the percentage decreased among patients with chronic and various diseases reaching the percentage of $(5.7 \%)$ and $(4.3 \%)$, respectively. A strong relationship of statistical significance was found $(\mathrm{P}=0.000)$ between the age group and type of disease. A study in correlation to determine the direction of the relationship was found that it was proportional $(\mathrm{P}=0.54)$, i.e. the disease increase with age. It was also found that chronic disease is more prevalent in the age group between (45-64 years old), and is consistent with (Musaiger, 2004) where it stated that chronic diseases increased with age and was due to following a lifestyle, food habits and health conditions.

As shown from Table (1) the level of education was low among inpatients, where $24.7 \%$ patients hold a secondary certificate, while $(22.9 \%)$ as intermediate certificate holders. The percentage of illiterate was $(13.3 \%)$ and all of them were females, university was $(10.8 \%)$, while $(7.8 \%)$ for read and write, and $(2.20 \%)$ of inpatients obtained primary certificate. It was evident in Table (1) that more than two-thirds of the samples $(69.9 \%)$ were married and $(23.5 \%)$ were not married, while the percentage of divorced and widowed patients represented (4.8\% and (1.8), respectively. As noted from Table (1) about two third of the sample $(64.5 \%)$ did not work in comparison to $(35.5 \%)$ who worked. The high proportion of unemployed patients may be due to health conditions, leading to an inability to provide sufficient food. Table (1) reflects a correlation between sample with different diseases, cancer and chronic diseases (48.9\%), (48.4\%) and (44.3\%), respectively, in terms of monthly income. The total monthly income of (77 patients) inpatients was (less than SR 3,000), while only about a quarter of respondents $(23.5 \%)$ of middleincome people was (less than 6,000 riyals), and converging percentage results were of high-income (less than 9,000 SR) and very high income (more than 9,000 riyals), (15.7\%) and (14.5\%), respectively.

\section{Evaluation of the nutritional status of inpatients.}

\section{First: Some physical parameters}

As indicated from Table (2) there was a great convergence of results for mean of arm circumference for respondents of cancer, various diseases and chronic diseases reaching $(31.90 \pm 4.69 \mathrm{~cm}),(31.52 \pm 4.7 \mathrm{~cm})$ and $(30.97 \pm 4.89 \mathrm{~cm})$, respectively. The total mean arm circumference of the sample was $(31.3 \pm 4.79 \mathrm{~cm})$, and indicated that the mid-arm circumference had a normal percentile degree of 50. This was in consistent with Bonnefoy (2002) where it was found that (11.3\%) of inpatients, especially people with chronic diseases had severely low mid-arm circumference, which is a good measurement to identify nutritional status, where measurement was $30.5 \mathrm{~cm}$ (the normal percentile degree 50 ), as it was associated with body mass index (BMI), the thickness of the layer of fat under the skin and some vital signs, such as albumin. 
Table 1. Social and economic characteristics of inpatients of the Department of Internal Medicine

\begin{tabular}{|c|c|c|c|c|c|c|c|c|}
\hline \multirow[t]{3}{*}{ Sex } & \multicolumn{6}{|c|}{ Type of disease } & \multirow{2}{*}{\multicolumn{2}{|c|}{ Total }} \\
\hline & \multicolumn{2}{|c|}{ Cancer No. = 31} & \multicolumn{2}{|c|}{$\begin{array}{c}\text { Chronic diseases } \\
\text { No. }=\mathbf{8 8} \\
\end{array}$} & \multicolumn{2}{|c|}{$\begin{array}{c}\text { Various diseases } \\
\text { No. }=47 \\
\end{array}$} & & \\
\hline & No. & $\%$ & No. & $\%$ & No. & $\%$ & No. & $\%$ \\
\hline Male & 15 & 16.9 & 58 & 64.4 & 17 & 18.9 & 90 & 100 \\
\hline Female & 16 & 21.0 & 30 & 39.5 & 30 & 39.5 & 76 & 100 \\
\hline Statistical relationship & \multicolumn{2}{|c|}{ Chi square $=11.438$} & \multicolumn{2}{|c|}{ Level of significance } & \multicolumn{2}{|c|}{0.003} & \multicolumn{2}{|c|}{ Significant } \\
\hline \multicolumn{9}{|c|}{ Age group (years old) } \\
\hline $16-19$ & 8 & 53.3 & 5 & 33.3 & 2 & 13.4 & 15 & 100 \\
\hline $20-44$ & 14 & 16.1 & 38 & 43.7 & 35 & 40.2 & 87 & 100 \\
\hline $45-64$ & 9 & 14.1 & 45 & 70.3 & 10 & 15.6 & 64 & 100 \\
\hline Statistical relationship & \multicolumn{2}{|c|}{ Chi square $=2.553$} & \multicolumn{2}{|c|}{ Level of significance } & \multicolumn{2}{|c|}{0.000} & \multicolumn{2}{|c|}{ Significant } \\
\hline \multicolumn{9}{|c|}{ Educational level } \\
\hline Read and write & 3 & 8.6 & 25 & 71.4 & 7 & 20.0 & 35 & 100 \\
\hline Primary & 8 & 23.5 & 17 & 50.0 & 9 & 26.5 & 34 & 100 \\
\hline Middle & 8 & 21.1 & 17 & 44.7 & 13 & 34.2 & 38 & 100 \\
\hline Secondary & 6 & 14.6 & 23 & 56.1 & 12 & 29.3 & 41 & 100 \\
\hline University & 6 & 33.3 & 6 & 33.3 & 6 & 33.4 & 18 & 100 \\
\hline $\begin{array}{l}\text { Statistical } \\
\text { relationship }\end{array}$ & \multicolumn{2}{|c|}{ Chi square $=1.949$} & \multicolumn{2}{|c|}{ Level of significance } & \multicolumn{2}{|c|}{0.130} & \multicolumn{2}{|c|}{ Not Significan } \\
\hline \multicolumn{9}{|c|}{ Marital status } \\
\hline Unmarried & 10 & 25.6 & 18 & 46.2 & 11 & 28.2 & 39 & 100 \\
\hline Married & 17 & 14.7 & 64 & 55.2 & 35 & 30.1 & 116 & 100 \\
\hline Divorced & 3 & 37.5 & 4 & 50.0 & 1 & 12.5 & 8 & 100 \\
\hline Widowed & 1 & 33.3 & 2 & 66.7 & - & - & 3 & 100 \\
\hline $\begin{array}{l}\text { Statistical } \\
\text { relationship }\end{array}$ & \multicolumn{2}{|c|}{ Chi square $=1.653$} & \multicolumn{2}{|c|}{ Level of significance } & \multicolumn{2}{|c|}{0.405} & \multicolumn{2}{|c|}{ Not Significant } \\
\hline \multicolumn{9}{|c|}{ Type of work } \\
\hline Works & 9 & 15.3 & 35 & 59.3 & 15 & 25.4 & 59 & 100 \\
\hline Does not work & 22 & 20.6 & 53 & 49.5 & 32 & 29.9 & 107 & 100 \\
\hline Statistical relationship & \multicolumn{2}{|c|}{ Chi square $=1.029$} & \multicolumn{2}{|c|}{ Level of significance } & & & Not & cant \\
\hline & & & Mor & ncome & & & & \\
\hline Less than *SR 3000 & 15 & 19.5 & 39 & 50.6 & 23 & 29.9 & 77 & 100 \\
\hline SR $3001-6000$ & 9 & 23.1 & 21 & 53.8 & 9 & 23.1 & 39 & 100 \\
\hline SR $6001-9000$ & 4 & 15.4 & 14 & 5308 & 8 & 30.8 & 26 & 100 \\
\hline SR 9000 and more & 3 & 12.5 & 14 & 58.3 & 7 & 29.2 & 24 & 100 \\
\hline $\begin{array}{l}\text { Statistical } \\
\text { relationship }\end{array}$ & Chi sc & $=0.532$ & Level o & ficance & & & & \\
\hline
\end{tabular}


Table 2. Mean of some physical parameters of inpatients at the Department of Internal Medicine

\begin{tabular}{|c|c|c|c|c|c|c|c|c|c|}
\hline \multirow{2}{*}{$\begin{array}{l}\text { Mean of some } \\
\text { physical parameters }\end{array}$} & \multicolumn{6}{|c|}{ Type of disease } & \multirow{2}{*}{$\begin{array}{c}\text { Chi } \\
\text { square }\end{array}$} & \multirow{2}{*}{\multicolumn{2}{|c|}{ Significance }} \\
\hline & $\begin{array}{l}\text { Chronic } \\
\text { diseases }\end{array}$ & \multicolumn{2}{|c|}{ Cancer } & $\begin{array}{l}\text { rious } \\
\text { eases }\end{array}$ & \multicolumn{2}{|c|}{ Total } & & & \\
\hline $\begin{array}{l}\text { Mid-arm } \\
\text { circumference }(\mathrm{cm})\end{array}$ & $31.9 \pm 4.69$ & \multicolumn{2}{|c|}{$30.97 \pm 4.89$} & $31.52 \pm 4.7$ & \multicolumn{2}{|c|}{$31.3 \pm 4.79$} & 11.653 & \multicolumn{2}{|c|}{$\begin{array}{c}0.008 \\
\text { Significant }\end{array}$} \\
\hline $\mathrm{BMI}(\mathrm{kg} \pm / \mathrm{m} 2)$ & $6.16 \pm 7.41$ & $25.35 \pm$ & \multicolumn{2}{|c|}{$27.52 \pm 7.42$} & \multicolumn{2}{|c|}{$26.12 \pm 7.23$} & 1.39 & \multicolumn{2}{|c|}{$\begin{array}{c}0.25 \mathrm{Not} \\
\text { significant }\end{array}$} \\
\hline \multirow{2}{*}{\multicolumn{2}{|c|}{ Mean of some physical parameters }} & \multicolumn{8}{|c|}{ Type of disease } \\
\hline & & \multicolumn{2}{|c|}{$\begin{array}{c}\text { Chronic } \\
\text { diseases }\end{array}$} & \multicolumn{2}{|c|}{ Cancer } & \multicolumn{2}{|c|}{$\begin{array}{l}\text { Various } \\
\text { diseases }\end{array}$} & \multicolumn{2}{|c|}{ Total } \\
\hline Male & & No. & $\%$ & No. & $\%$ & No. & $\%$ & No. & $\%$ \\
\hline \multicolumn{2}{|c|}{ Low weight less than 20.7} & 4 & 16.70 & 6 & 13.60 & 6 & 6.10 & 16 & 9.50 \\
\hline \multicolumn{2}{|c|}{ Acceptable weight $20.7-27.8$} & 4 & 16.70 & 13 & 29.50 & 31 & 31.60 & 48 & 28.90 \\
\hline \multicolumn{2}{|c|}{ Overweight more than 27.8} & 3 & 12.50 & 2 & 4.50 & 5 & 5.10 & 10 & 6 \\
\hline \multicolumn{2}{|c|}{ Severe overweight more 31.1} & - & - & 3 & 6.80 & 9 & 9.20 & 12 & 7.20 \\
\hline \multicolumn{2}{|c|}{$\begin{array}{l}\text { Morbid obesity more than } 45.4 \\
\text { Female }\end{array}$} & 1 & 4.20 & - & - & 2 & 2 & 3 & 1.8 \\
\hline \multicolumn{2}{|c|}{ Low weight less than 19.1} & 1 & 4.20 & 6 & 13.60 & 6 & 6.10 & 13 & 7.80 \\
\hline \multicolumn{2}{|c|}{ Acceptable weight $19.2-27.3$} & 6 & 25 & 5 & 11.40 & 20 & 20.40 & 31 & 18.70 \\
\hline \multicolumn{2}{|c|}{ Overweight more than 27.3} & 1 & 4.20 & 3 & 6.80 & 6 & 6.10 & 10 & 6 \\
\hline \multicolumn{2}{|c|}{ Severe overweight more 32.3} & 4 & 16.70 & 5 & 11.40 & 11 & 11.20 & 20 & 12 \\
\hline \multicolumn{2}{|c|}{ Morbid obesity more than 44.8} & - & - & 1 & 2.30 & 2 & 2 & 3 & 1.80 \\
\hline \multicolumn{2}{|c|}{ Statistical relationship } & \multicolumn{3}{|c|}{ Chi square $=16.249$} & \multicolumn{2}{|c|}{$\mathrm{P}=0.528$} & \multicolumn{3}{|c|}{ Not significant } \\
\hline
\end{tabular}

Table (2) showed that the mean body mass index (BMI) of the sample with various diseases was $(27.52 \pm 7.42$ $\left.\mathrm{kg} / \mathrm{m}^{2}\right)$, and $\left(26.16 \pm 7.41 \mathrm{~kg} / \mathrm{m}^{2}\right),\left(25.35 \pm 7.03 \mathrm{~kg} / \mathrm{m}^{2}\right)$ in both cancer and chronic diseases patients respectively.

The general mean of body mass index (BMI) of inpatients was $\left(26.12 \pm 7.23 \mathrm{~kg} / \mathrm{m}^{2}\right)$, and which indicated that the weight of the inpatients were acceptable and not referred obese. This was in agreement with Shum, et al. (2005) where it was found that the mean of body mass index (BMI) of males and females inpatients reached $(21.9 \pm 4.4 \mathrm{~kg})$. Also it was found that $(16.7 \%)$ were under weight (less than $18.5 \mathrm{~kg}$ ). The results differed from the previous study of (De Luis, et al., 2006) where it was noted that the mean weight of inpatients was $(63.5 \pm 14.5 \mathrm{~kg})$.

As shown in Table (3) showed the intake of calories was found that the majority of respondents with various diseases and chronic diseases were $(92.3 \%)$ and $(80 \%)$, respectively, and $(71 \%)$ of cancer patients consumed less than adequate, while intakes of $(22.6 \%),(14 \%)$ and $(7.7 \%)$ of respondents with cancer, chronic diseases and various diseases respectively were more than adequate. Also, it was found that only $(6.5 \%)$ and $(6 \%)$ of respondents suffering from chronic diseases and cancer, respectively consumed adequate calories per day.
Generally, it was noted that the majority of respondents $80.4 \%$, was taking less than adequate calories per day, while $15 \%$ was taking more than adequate, and $4.7 \%$ was taking adequate calories per day.

Consistent results were found in agreement with previous studies that had researched to identify the amount of calories consumed per day for hospital inpatients, which had observed a low intake of calories per day. It had been found by Perier, et al. (2004) that mean intake of calories for inpatients was decreased for those who benefited with stability of their health conditions which reached $(1535 \pm 370 \mathrm{kcal} /$ day $)$, and also decreased in those with acute infections up to (1375 $\pm 500 \mathrm{kcal} /$ day).

Table (3) showed inpatients (87.1\%) consumed more than the adequate recommended intake of carbohydrates, while the percentage of patient who consumed less than adequate and adequate intake represented $(9.7 \%)$ and $(4.7 \%)$ of the total sample, respectively. As referred to by Perier, et al. (2004) that the mean daily intake of carbohydrates for inpatients that benefited stability of health conditions reached $(55 \pm 7.7 \%)$, while it was less for patients suffering from severe diseases such as heart and respiratory problems and reached $(54 \pm 8.3 \%)$. As shown from Table (3) the daily intake of protein for about two third $(69.2 \%)$ of the sample with various diseases and about half $(54.8 \%),(54 \%)$ of those with 
Table 3. Percentages of adequacy of the sample nutrients intake by 24 hours recall

\begin{tabular}{|c|c|c|c|c|c|c|c|}
\hline \multirow[t]{3}{*}{ Nutrients } & \multirow[t]{3}{*}{ Adequate } & \multicolumn{3}{|c|}{$\begin{array}{c}\text { Type of disease } \\
\end{array}$} & \multirow[t]{3}{*}{ Total } & \multirow{3}{*}{$\begin{array}{l}\text { Percentage } \\
\text { value } \\
\text { Chi square } \\
\text { test }\end{array}$} & \multirow[t]{3}{*}{ Significance } \\
\hline & & $\begin{array}{l}\text { Chronic } \\
\text { diseases }\end{array}$ & Cancer & $\begin{array}{l}\text { Various } \\
\text { diseases }\end{array}$ & & & \\
\hline & & $\%$ & $\%$ & $\%$ & & & \\
\hline \multirow{3}{*}{$\begin{array}{l}\text { Energy (calorie } \\
\text { per day) }\end{array}$} & Less than adequate & 71 & 80 & 92.3 & 80.4 & \multirow[t]{3}{*}{4.71} & Not \\
\hline & Adequate & 6.5 & 6 & - & 4.7 & & significant \\
\hline & More than adequate & 22.6 & 14 & 7.7 & 15 & & 0.131 \\
\hline \multirow{3}{*}{$\begin{array}{l}\text { Carbohydrates } \\
\text { (g) }\end{array}$} & Less than adequate & 23 & - & 15.4 & 4.7 & \multirow[t]{3}{*}{7.873} & \multirow{3}{*}{$\begin{array}{c}\text { Significant } \\
0.005\end{array}$} \\
\hline & Adequate & 9.7 & 6 & 11.5 & 9.6 & & \\
\hline & More than adequate & 87.1 & 94 & 73.1 & 87.1 & & \\
\hline \multirow[t]{3}{*}{ Protein (g) } & Less than adequate & 38.7 & 44 & 23.1 & 37.4 & \multirow[t]{3}{*}{1.903} & \multirow{3}{*}{$\begin{array}{c}\text { Not } \\
\text { significant } \\
0.512\end{array}$} \\
\hline & Adequate & 54.8 & 54 & 69.2 & 57.9 & & \\
\hline & More than adequate & 6.5 & 2 & 7.7 & 4.7 & & \\
\hline \multirow{4}{*}{$\begin{array}{l}\text { Fat (g) } \\
\text { Vitamin A } \\
\text { (micrograms) }\end{array}$} & Less than adequate & 100 & 100 & 100 & 100 & \multicolumn{2}{|c|}{ Total less than adequate } \\
\hline & Less than adequate & 83.9 & 94 & 100 & 92.5 & \multirow[t]{3}{*}{4.903} & \multirow{3}{*}{$\begin{array}{c}\text { Not } \\
\text { significant } \\
0.062\end{array}$} \\
\hline & Adequate & 6.5 & 4 & - & 3.7 & & \\
\hline & More than adequate & 16.1 & 6 & - & 7.5 & & \\
\hline \multirow{3}{*}{$\begin{array}{l}\text { Vitamin C } \\
\text { (mg) }\end{array}$} & Less than adequate & 83.9 & 96 & 96.2 & 92.5 & \multirow[t]{3}{*}{3.932} & \multirow{3}{*}{$\begin{array}{c}\text { Not } \\
\text { significant } \\
0.131 \\
\end{array}$} \\
\hline & Adequate & - & 2 & 3.8 & 1.9 & & \\
\hline & More than adequate & 16.1 & 4 & 3.8 & 7.5 & & \\
\hline \multirow{3}{*}{$\begin{array}{l}\text { Thiamine (B1) } \\
\text { (mg) }\end{array}$} & Less than adequate & 67.7 & 72 & 76.9 & 72 & 3.526 & \multirow{3}{*}{$\begin{array}{c}\text { Not } \\
\text { significant } \\
0.198\end{array}$} \\
\hline & Adequate & 12.9 & 10 & 19.2 & 13.1 & & \\
\hline & More than adequate & 19.4 & 18 & 3.8 & 15 & & \\
\hline \multirow{3}{*}{$\begin{array}{l}\text { Riboflavin (B2) } \\
\text { (mg) }\end{array}$} & Less than adequate & 41.9 & 49 & 42.3 & 44.9 & \multirow[t]{3}{*}{1.091} & \multirow{3}{*}{$\begin{array}{c}\text { Not } \\
\text { significant } \\
0.602 \\
\end{array}$} \\
\hline & Adequate & 22.6 & 24 & 34.6 & 26.2 & & \\
\hline & More than adequate & 35.5 & 28 & 23.1 & 29 & & \\
\hline \multirow[t]{2}{*}{$\overline{\text { Niacin (mg) }}$} & Less than adequate & 100 & 92 & 92.3 & 94.4 & \multirow[t]{2}{*}{3.579} & Not \\
\hline & Adequate & - & 8 & 7.7 & 5.6 & & $\begin{array}{c}\text { significant } \\
0.165\end{array}$ \\
\hline Iron (mg) & Less than adequate & 16.1 & 22 & 38.5 & 24.3 & 3.874 & Not \\
\hline & Adequate & 77.4 & 64 & 57.7 & 66.4 & & significant \\
\hline & More than adequate & 6.5 & 14 & 7.7 & 10.3 & & 0.131 \\
\hline Calcium (mg) & Less than adequate & 96.8 & 100 & 100 & 99.1 & 2.235 & Not \\
\hline & More than adequate & 3.2 & - & - & 0.9 & & $\begin{array}{c}\text { significant } \\
0.529\end{array}$ \\
\hline Phosphorus & Less than adequate & 35.5 & 26 & 42.3 & 32.7 & 271.2 & $1.321 \mathrm{Not}$ \\
\hline$(\mathrm{mg})$ & Adequate & 12.9 & 16 & 7.7 & 13.1 & & significant \\
\hline & More than adequate & 51.6 & 58 & 50 & 54.2 & & \\
\hline
\end{tabular}

cancer and chronic diseases, respectively consumed daily an adequate amount of protein. Intakes with less than adequate were $(44 \%),(38.7 \%)$ and $(23.1 \%)$ for those with chronic diseases, cancer and various diseases, respectively; whereas $(7.7 \%),(6.5 \%)$ and $(2 \%)$ of sample with various diseases, cancer and chronic diseases, respectively consumed more than the recommended daily intake of protein. A statistically significant relationship $(\mathrm{P}=0.004)$ was found between the mean intake of protein and type of the disease.
As explained by Perier, et al., (2004) that the mean daily intake of protein for inpatients who benefited stability of health conditions was $(1 \pm 0.4 \mathrm{~g} / \mathrm{kg} / \mathrm{day})$, while the mean intake decreased for patients suffering from severe diseases such as heart and respiratory diseases and reached $(0.9 \pm 0.4 \mathrm{~g} / \mathrm{kg} / \mathrm{day})$. The result also was in agreement with Lassen, et al. (2005) where it was found that $30-50 \%$ of hospital inpatients were suffering from protein and calorie deficiencies. 
As indicated in Table (3) the daily fat intake was found that all the studied patients (100\%) consumed less than the recommended daily intake. These results are in agreement with those of Clelland and Williams (2003) where they indicated a lower amount of fatty foods in the lists provided to inpatients. Therefore, there was no statistical significant relationship between fat intake and the type of disease. As mentioned by Perier, et al. (2004) the mean daily fat intake for inpatients that benefited stable health conditions was $(30 \pm 6.3 \mathrm{~g} /$ day $)$ while the mean intake for patients suffering from severe diseases such as heart and respiratory diseases reached $31 \pm 6.2 \mathrm{~g} /$ day.

Table (3) showed that vitamin A intake per day was found that $(100 \%)$ of patients suffering from various diseases and the majority of patients with chronic diseases and cancer (94\%) and (83.90\%) respectively, consumed less than the adequate vitamin A per day; while $16.10 \%$ and $6 \%$ of cancer patients and chronic diseases, respectively, taking more than the adequate, and only $(6.50 \%)$ and (4\%) of patients with cancer and chronic diseases, respectively, taking the adequate intake of vitamin A. Thus, the majority of inpatients $(92.50 \%)$ were taking less than what they require of vitamin A per day. The results of the study were in agreement with (Abdel kader, 2001)_with different ratios as reported with $(20 \%)$ of inpatients suffering from vitamin A deficiency.

As shown from Table (3) the majority of respondents with various diseases, chronic diseases and cancer (96.20\%), (96\%) and (83.90\%), respectively, consumed less than what they require of vitamin $\mathrm{C}$; in contrast $(16.10 \%),(4 \%)$ and $(3.80 \%)$ of patients with cancer, chronic diseases and various diseases respectively, were taking more than the adequate intake. In general, the majority of respondents consumed less than adequate intake of vitamin C (92.50\%), and (7.50\%) taking higher than adequate, while only $(1.90 \%)$ of the sample taking adequate amount of vitamin C. A significant relationship was found $(\mathrm{P}=0.031)$ between the mean intake of vitamin $\mathrm{C}$ and type of disease. Consistent results with previous study (Perret, et al., 2004) showed where it was found that inpatients suffered scurvy due to lack of vitamin $\mathrm{C}$, despite providing them with a dose of up to $130 \mathrm{mg} /$ day.

Table (3) showed the thiamine intake per day. It was found that $(76.90 \%),(72 \%)$ and $(67.70 \%)$ of sample with various diseases, chronic diseases and cancer, respectively, consumed less than the adequate daily intake of thiamine, as opposed to $(19.40 \%),(18 \%)$ and $(3.80 \%)$ with cancer, chronic and various diseases respectively, taking more than the adequate. There was no statistical significant relationship between the mean intake of vitamin B-1 and type of disease.

As indicated from Table (3) the adequacy of niacin intake, there were less adequate of intake for respondents with cancer, various diseases and chronic diseases $100 \%$, $92.3 \%$ and $92 \%$, respectively versus low intake in $8 \%$ and $7.70 \%$ of respondents with chronic and various diseases, respectively. There was no statistical significant relationship between the mean intake of niacin per day and type of the disease.

It is noted that $(66.40 \%)$ of total patients consumed adequate intake of iron, compared with less than adequate and more than adequate intake which reached $24.30 \%, 10.30 \%$, respectively. A statistically significant relationship was found $(\mathrm{P}=0.006)$ between the intake of iron and the level of food awareness where the value of chi square test $=9.738$. This is an indicator of the role of food awareness to change and modify the nutritional status of the inpatients. There is no significant relationship between intake of iron and the type of disease (Hijazi, 2002). 35\% of inpatients did not take the necessary requirements of iron daily (Table 3 ).

Table (3) showed that most respondents with chronic, various diseases and cancers $100 \%, 100 \%$ and $96.80 \%$, respectively, were taking less than adequate calcium per day; while $(3.2 \%)$ of cancer patients had an intake more than the adequate. There was no statistical significant relationship $(\mathrm{P}=0.302)$ between the mean of calcium intake and type of disease. And as referred to Perier, et al. (2004) the mean daily intake of calcium for inpatients who had stable health conditions was $918 \pm 341 \mathrm{mg}$, while the mean intake for patients suffering from severe diseases such as heart and respiratory disease had reached $866 \pm 379 \mathrm{mg} /$ day.

It was indicated from Table (3) that (58\%), (51.6\%) and $(50 \%)$ of respondents with chronic diseases, cancer and various diseases, respectively consumed more than the adequate intake of phosphorus, and $42.3 \%, 35.5 \%$ and $26 \%$ of respondents with various diseases, cancer and chronic diseases consumed less than adequate. There was no statistical significant relationship between the mean intake of phosphorus and type of disease. Generally, a statistically significant relationship was found $(\mathrm{P}=0.03)$ where the value of Fisher test $=3.351$ between adequacy rate of vital nutrients and type of disease.

\section{III - Laboratory Assessment:}

As shown in Table (4) there is an increase in mean albumin among cancer patients $(45.82 \pm 28.82 \mathrm{mg} /$ liter), and normal in respondents with chronic and various diseases by $(17.76 \pm 26.21 \mathrm{mg} /$ liter $)$ and (14.49 $\pm 23.42 \mathrm{mg} /$ liter), respectively. Generally, the mean 
albumin of inpatients was found to be in normal range $(23.15 \pm 28.59 \mathrm{mg} / \mathrm{l})$. A statistically significant relationship $(\mathrm{P}=0.000)$ was found between the level of albumin in the blood and the type of disease. Almakhallilaty (1997) mentioned that the level of albumin decreases in blood in case of severe malnutrition and malabsorption and with liver disease, kidney, pancreas and congestive heart failure. The data in Table (4) indicates that the mean level of creatinine for respondents with chronic diseases, cancer and various diseases was $(59.3 \pm 204.21 \mathrm{mg} / 100 \mathrm{ml})$, $(46.45 \pm 41.78 \mathrm{mg} / 100 \mathrm{ml})$ and $(13.36 \pm 24.08 \mathrm{mg} /$ $100 \mathrm{ml})$, respectively, and thus the general average for inpatients creatinine was within normal range (44.43 $\pm 153.13 \mathrm{mg} / 100 \mathrm{ml}$ ). A strong relationship of statistical significance $(\mathrm{P}=0.000)$ was found between creatinine level and type of disease. The creatinine index is considered used in hospitals to identify malnutrition due to lack of protein and calories, and in general there was a decline in the level of creatinine in the urine when the body used muscle protein as source of energy (Almakhallilaty, 1997).

Table (4) showed the level of white blood cells in cancer patients, various diseases and chronic diseases by $75 \%, 65.30 \%$ and $59.10 \%$, respectively which within the normal range; a high level by $36.40 \%, 33.70 \%$ and $8.30 \%$ of respondents with chronic diseases, various diseases and cancers, respectively; and low level by $16.70 \%$ of respondents with cancer and $4.50 \%, 1 \%$ of respondents with chronic and various diseases, respectively. There was no statistical significant relationship between the level of white blood cells and the type of disease. Almakhallilaty (1997) mentioned that the level of white blood cells increased due to leukemia or acute infection or dehydration, where lowlevel naturally occur with malnutrition, severe infection and radiation therapy.

As shown in Table (4) mean levels of hematocrit converged by $33.12 \pm 11.19 \%, 32.47 \pm 7.6 \%$ and 32.38 $\pm 10.32 \%$ for respondents with various diseases, cancer and chronic diseases, respectively. Generally, it was found that the total mean hematocrit of inpatients was low $32.61 \pm 10.08 \%$, and in more than half of the inpatients. There was no statistical significant relationship between hematocrit level and type of disease. Almakhallilaty (1997) noted that estimation of hematocrit was considered more accurate than hemoglobin for determining the level of anemia in the patient.

\section{Table 4. Level of plasma albumin, creatinine in urine, white blood cells and hematocrit of the research samples}

\begin{tabular}{|c|c|c|c|c|c|c|c|c|c|}
\hline \multirow{3}{*}{\multicolumn{2}{|c|}{$\begin{array}{l}\text { Plasma albumin } \\
\text { level (mg/l) }\end{array}$}} & \multicolumn{6}{|c|}{ Type of disease } & \multirow{2}{*}{\multicolumn{2}{|c|}{ Total }} \\
\hline & & \multicolumn{2}{|c|}{ Cancer } & \multicolumn{2}{|c|}{ Chronic diseases } & \multicolumn{2}{|c|}{ Various diseases } & & \\
\hline & & No. & $\%$ & No. & $\%$ & No. & $\%$ & No. & $\%$ \\
\hline Low & $<1.3$ & - & - & 1 & 2.3 & 1 & 4 & 2 & 2.2 \\
\hline Normal & $1.3-24.9$ & 3 & 25 & 29 & 65.9 & 18 & 72 & 50 & 56.2 \\
\hline High & 24.9 & 17 & 85 & 14 & 31.8 & 6 & 24 & 37 & 41.2 \\
\hline $\begin{array}{l}\text { Statistical } \\
\text { relationsh }\end{array}$ & & & uare $=$ & & & $\mathrm{P}=0.0$ & & & ant \\
\hline \multicolumn{10}{|c|}{ The level of creatinine in the urine $(\mathrm{mg} / 100 \mathrm{ml})$} \\
\hline Low & $<30$ & 6 & 25 & 63 & 87.5 & 29 & 80.6 & 98 & 74.2 \\
\hline Normal & $30-125$ & 16 & 66.7 & 3 & 4.2 & 7 & 19.4 & 26 & 19.7 \\
\hline High & $>135$ & 2 & 8.3 & 6 & 8.3 & - & - & 8 & 6.1 \\
\hline $\begin{array}{l}\text { Statistical } \\
\text { relationsh }\end{array}$ & & & uare $=$ & & & $\mathrm{P}=0.00$ & & & ant \\
\hline \multicolumn{10}{|c|}{ Level of white blood cells } \\
\hline Low & $<4$ & 4 & 16.70 & 2 & 4.50 & 1 & 1 & 7 & 4.20 \\
\hline Normal & $4-11$ & 18 & 75 & 26 & 59.10 & 64 & 65.30 & 1.8 & 65.10 \\
\hline High & $>11$ & 2 & 8.30 & 16 & 36.40 & 33 & 33.70 & 51 & 30.70 \\
\hline $\begin{array}{l}\text { Statistical } \\
\text { relationsh }\end{array}$ & & & uare $=$ & & & $\mathrm{P}=0.0$ & & Not & icant \\
\hline \multicolumn{10}{|c|}{ Hematocrit level \% } \\
\hline Low & $<37$ & 24 & 77.40 & 45 & 61.40 & 33 & 70.20 & 111 & 66.90 \\
\hline Normal & $37-47$ & 7 & 22.60 & 33 & 37.50 & 12 & 25.50 & 52 & 31.30 \\
\hline High & $>47$ & - & - & 1 & 10.10 & 2 & 4.30 & 3 & 1.80 \\
\hline $\begin{array}{l}\text { Statistical } \\
\text { relationsh }\end{array}$ & & & uare $=$ & & & $\mathrm{P}=0.23$ & & Not & icant \\
\hline
\end{tabular}


Low hematocrit in the blood due to anemia or bleeding or chronic infection or to an increase in the level of body fluids, and the high level of blood were due to two possibilities: first, dehydration and second, possibility of Polycythemia (the increase in the number of red blood cells from the usual rates as a result of dehydration or any other reason).

Table (5) indicated convergence of results between the mean red blood cells $4.5 \pm 1.36$ cubic microns, 4.34 \pm 1.04 cubic microns and $4.28 \pm 1.07$ cubic microns for respondents with various diseases, cancer and chronic diseases, respectively, and the mean red blood cells for the total sample was in the normal range $4.36 \pm 1.15$ cubic microns. Almakhallilaty (1997) mentioned that the level of red blood cells indicates low anemia or dehydration. As shown from Table (5) hemoglobin level for males and females, where it was low by $38 \%, 31 \%$ and $17 \%$ for those with cancer, chronic diseases and various diseases, respectively; normal by $30 \%, 19.10 \%$ and $9.70 \%$ of respondents with chronic diseases, various diseases and cancers, respectively; and high by $2.10 \%$ and $1.10 \%$ for respondents with various diseases and chronic diseases, respectively.

As the above table indicated there were low levels of hemoglobin in females by $38.30 \%, 32.30 \%$ and $18.20 \%$ of women with various diseases, cancer and chronic diseases, respectively; and normal by $23.40 \%, 19.40 \%$ and $18.20 \%$ of women with various diseases, cancer and chronic diseases, respectively. This was in consistent with the study of Badruddin, et al. (1999) which indicated that the percentage of hemoglobin $(58 \%)$ of inpatients was less than $\left(12 \mathrm{~g} / \mathrm{cm}^{3}\right)$.

Likewise, as the above table indicated, a convergence results between the mean hemoglobin for respondents with various diseases, chronic diseases and cancer reached $(11.99 \pm 4.01 \mathrm{~g} / \mathrm{cm} 3),(11.92 \pm 2.99 \mathrm{~g} / \mathrm{cm} 3)$ and $(10.97 \pm 2.67 \mathrm{~g} / \mathrm{cm} 3)$, respectively; and in general the mean hemoglobin in inpatients was $(11.76 \pm 3.26 \mathrm{~g} / 100$ $\mathrm{cm} 3$ ), and the percentages given showed more detailed results for the hemoglobin level of inpatients. Also, a statistically significant relationship $(\mathrm{P}=0.003)$ was found between hemoglobin level and type of disease.

Table 5. Red blood cells and hemoglobin levels of inpatients of the Department of Internal Medicine in some hospitals in Jeddah

\begin{tabular}{|c|c|c|c|c|c|c|c|c|c|}
\hline \multirow{2}{*}{\multicolumn{2}{|c|}{$\begin{array}{l}\text { Level of red blood } \\
\text { cells (cubic/micron) }\end{array}$}} & \multicolumn{6}{|c|}{ Type of disease } & \multirow{2}{*}{\multicolumn{2}{|c|}{ Total }} \\
\hline & & \multicolumn{2}{|c|}{$\begin{array}{l}\text { Cancer } \\
(\mathrm{N}=24)\end{array}$} & \multicolumn{2}{|c|}{$\begin{array}{c}\text { Chronic diseases } \\
\qquad(\mathrm{N}=44)\end{array}$} & \multicolumn{2}{|c|}{$\begin{array}{l}\text { Various diseases } \\
\qquad(\mathrm{N}=98)\end{array}$} & & \\
\hline \multicolumn{2}{|c|}{ Males } & No. & $\%$ & No. & $\%$ & No. & $\%$ & No. & $\%$ \\
\hline Low & $<3.8$ & 2 & 8.30 & 12 & 27.30 & 13 & 13.03 & 27 & 16.30 \\
\hline Normal & $3.8-5.8$ & 9 & 37.50 & 9 & 20.50 & 30 & 30.60 & 48 & 28.90 \\
\hline High & $>5.8$ & - & - & - & - & 2 & 2 & 2 & 1.20 \\
\hline \multicolumn{10}{|l|}{ Females } \\
\hline Low & $<4.5$ & 7 & 29.20 & 11 & 25 & 17 & 17.30 & 35 & 21.10 \\
\hline Normal & $4.5-6.5$ & 5 & 20.80 & 11 & 25 & 35 & 35.70 & 51 & 30.70 \\
\hline High & $>6.5$ & 1 & 4.20 & 1 & 2.30 & 1 & 1 & 3 & 1.80 \\
\hline Statistica & lationship & Chi sc & $e=12.5$ & & $P=0.194$ & & & Not $\mathrm{Sig}$ & \\
\hline \multicolumn{10}{|c|}{ Hemoglobin level $\mathrm{g} / \mathrm{cm}^{3}$} \\
\hline \multicolumn{10}{|c|}{ Males } \\
\hline Low & $<13$ & 12 & 38.70 & 28 & 31.80 & 8 & 17 & 48 & 28.90 \\
\hline Normal & $13-18$ & 3 & 9.70 & 27 & 30.70 & 9 & 19.10 & 39 & 23.50 \\
\hline High & $>18$ & - & - & 1 & 1.10 & 1 & 2.10 & 2 & 1.20 \\
\hline \multicolumn{10}{|l|}{ Females } \\
\hline Low & $<11.5$ & 10 & 32.30 & 16 & 18.20 & 18 & 38.30 & 44 & 26.50 \\
\hline Normal & $11.5-16.5$ & 6 & 19.40 & 16 & 18.20 & 11 & 23.40 & 33 & 19.90 \\
\hline High & 16.5 & - & - & - & - & - & - & - & - \\
\hline \multicolumn{2}{|c|}{ Statistical relationship } & \multicolumn{3}{|c|}{ Chi square $=14.703$} & \multicolumn{3}{|c|}{$\mathrm{P}=0.003$} & \multicolumn{2}{|c|}{ Significant } \\
\hline
\end{tabular}


Disease affects the level of hemoglobin in the blood. Almakhllaty (1997) noted that the lack of hemoglobin level in the blood was significant for malnutrition, anemia (iron deficiency) or bleeding. Also, a statistically significant relationship $(\mathrm{P}=0.001)$, the value of $\mathrm{Chi}$ square $=38.782$ and between hemoglobin level and duration of treatment (stay) in the hospital were found. It also found a strong correlation and direct correlation $(\mathrm{P}=0000)$ and the value of $\mathrm{r}=0.718$ between hemoglobin level and body mass index, and hemoglobin and mid-arm circumference.

\section{REFERENCES}

Abdel kader, M. (2001): Assessment of nutritional status, the first edition, Cairo: Arab Nile Group.

Al-Hazza H.(2009): Physical measurements (anthropometric) to humans. A chapter in the book Nutrition Encyclopedia, edited by Abdul Rahman Obaid Musaiger, Bahrain Centre for Studies and Research, Manama - Bahrain, International Academy- Beirut - Lebanon, 432-464.

Al-Hazza H.(2010): Body mass index (BMI): Uses and misuses. Third Arab Conference for obesity and physical activity (19-21 January 2010). Kingdom of Bahrain.

Almakhallilaty, J. (1997):Manual feeding of patients in hospitals, First edition, Amman: Dar El Shorouk for publication and distribution.

Almakhallilaty, J. (2005): Nutrition Guide for patients in hospitals. First edition. Sunrise House for publication and distribution. Amman. Jordan.

AL-Shoshan, A.(1992):Study of regular diet of selected hospitals of the ministry of health in Saudi Arabia :Edible plate waste and its monetary value. Nutrition Department. Ministry of health, Riyadh. J. R. Soc. Health.112(1)7-11.

American Dietetic Association (2000): Position of American Dietetic Association: nutrition, aging and the continuum of care. Journal of American Dietetic Association. 100:580-595.

Arrow Smith, H. (1997) Malnutrition in hospital: detection and consequences. Br J. Nurs. 6(19):1131-1135.

Badruddin, S.; Jafri, S.; Ahmed, A. and Abid, S. (1999): Dietary practices and beliefs of patients with chronic liver disease. J Pak Med Assoc. 49(9):216-220.
Bonnefoy, M.; Jauffret, M.; Kostka, T. and Jusot, J. (2002): Usefulness of calf circurement in assessing the nutritional state of hospitalized elderly people, Gerontology. 48(3)162-169.

Cereceda , C.; Gonzalez , I.; Antolin , F.; Garcia , P.; Tarrazo , R.; Suarez , B.; Alvarez , A. and Manso , R. (2003): Detection of malnutrition on admission to hospital . Nutr Hosp. 18(2):95-100

Clelland, A. and Williams, P. (2003): Trend to better on Australian hospital menus 1986-2001 and the impact of cook-chill service. J Hum Nutr Diet, 16(4): 245-256.

De Luis, D.; lzaola, O.; Cuellar, L.; Terroba, M.; Cabezas, G. and Sagrado, M. (2006): Nutritional assessment: predictive variables at hospital admission related with length of stay. Ann -Nutro Metab. 50(4):394 - 398.

Food and Nutrition Board, Institute of Medicine: The Dietary Reference Intakes Series, National Academy Press. National Research Council (1997-2004), National Academy of Sciences, Washington, D.C. http://www.nap,edu.

Hijazi, H.(2002). Analysis and evaluation of the meals provided to patients in some government and private hospitals in Makkah. PhD thesis, College of Home Economics, Makkah - Kingdom of Saudi Arabia.

Lassen, K.; Kruse, F. and Bjerrum, M. (2005) Nutritional care of Danich medical inpatients, Scand, J. Caring Sci. (Sep) 19(3):259-67.

-Perier, C.; Trioulere, P.; Terrat, C.; Chomette, M.; Beauchet, O. and Gonthier, R. (2004): Energy and nutrient intake of elderly hospitalized patients in a steady metabolic status versus catabolic status, J. Nutr Health Aging. 8(6):518520.

Ravasco, P. ; Monteiro-Grillo, I. ;Vidal, P. and Camilo, M. (2004): Cancer: disease and nutrition are key determinants of patients' quality of life. Supportive Care in Cancer.12(4):246-252.

Shum, N.; Hui, W.; Chu, F. and Chow, T. (2005): Prevalence of malnutrition and risk factors in geriatric patients of a convalescent and rehabilitation hospital, Hong Kong Med. J. 11(4): 234-242.

SPSS Software Package for Statistical Analysis Version 15, November 2006

Ulibarri, Perez, J.; Picon Cesar, M.; Garcia Benavent, E. and Mancha Alvarez-Estrada, A. (2002): Early detection and control of hospital malnutrition. Section de Nutrition Clinical Dietetic, Hospital Nutr.17(3):139-146. 


\section{الملخص العربي}

\section{تقييم الحالة الغذائية للمرضى البالغين المنومين بقسم الباطنة ببعض مستشفيات جدة}

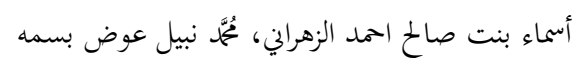

كان غالبية أفراد العينة يتناولون أقل من كفايتهم من السعرات

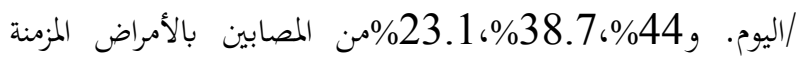

والسرطان والأمراض المختلفة على التوالي تناولوا أقل من كفايتهم من

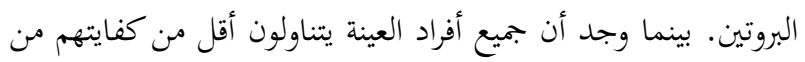

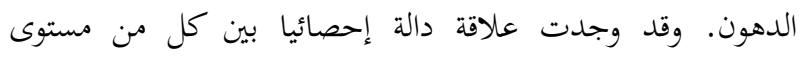

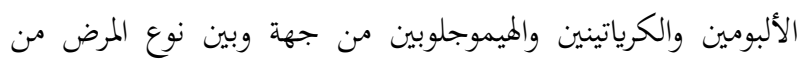
جهة أخرى. ولا توجد علاقة ذات دلالة إحصائية بين مستوى خلايا

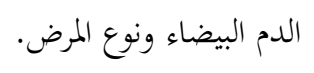

استهدفت هذه الدراسة تقييم الحالة الغذائية للمرضى البالغين المنومين بقسم الباطنة ببعض مستشفيات جدة. بلغ عدد أفراد العينة

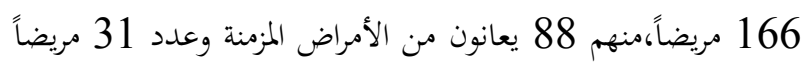

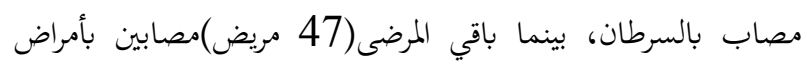

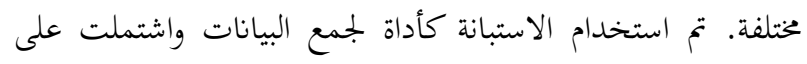
بيانات اجتماعية واقتصادية، وقد استخدم في الدراسة ثلاث طرق لتقييم الحالة الغذائية هي القياسات الأنثروبومترية، وتحديد مدى كفاية العناصر الغذائية المتناولة والتحاليل المعملية. قد أظهرت النتائج أن الن النيات متوسط مؤشر كتلة الجسم للمرضى المنومين كان (26.12 ـ 7.23

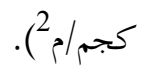

